\title{
Analysis of structure-selectivity relationships through single- or dual step selectivity searching using 2D molecular fingerprints D Stumpfe, H Geppert and J Bajorath*
}

\author{
Address: Department of Life Science Informatics, B-IT, LIMES Program Unit Chemical Biology and Medicinal Chemistry, Rheinische Friedrich- \\ Wilhelms-Universtität Bonn, Dahlmannstr. 2, D-53113 Bonn, Germany \\ * Corresponding author
}

from 4th German Conference on Chemoinformatics

Goslar, Germany. 9-II November 2008

Published: 5 June 2009

Chemistry Central Journal 2009, 3(Suppl I):P4 doi:10.1I86/I752-I53X-3-SI-P4

This abstract is available from: http://www.journal.chemistrycentral.com/content/3/SI/P4

(C) 2009 Stumpfe et al; licensee BioMed Central Ltd.

The identification of small molecules displaying different selectivity patterns against a protein target is a prerequisite to interfere with functions of individual members of protein families [1]. For computational methods it is more difficult to study selectivity than activity because selectivity analysis requires the evaluation of compounds binding to multiple targets [2].

We aim at the development of computational approaches for the study of structure-selectivity relationships and prediction of target-selective ligands. Therefore, we have designed 18 selectivity sets containing target-selective molecules and compounds that are comparably active against related targets (and thus non-selective). This compound collection of a total of 432 compounds focuses on eight targets belonging to four protein families and has enabled us to evaluate different in silico approaches to search for target-selective compounds [3].

The results further support previous findings that even low-complexity structure-based 2D fingerprints are capable of identifying compounds having different selectivity against closely related target proteins and revealed a preferred search strategy to enrich database selection sets with target-selective compounds [4][5].

\section{References}

I. Stockwell BR: Nature 2004, 432:846-854.

2. Bajorath J: Curr Opin Chem Biol 2008, I 2:352-358.

3. Stumpfe D, Geppert H, Bajorath J: Chem Biol Drug Des 2008, $71: 518-528$.
4. Stumpfe D, Ahmed HEA, Vogt I, Bajorath J: Chem Biol Drug Des 2007, 70:182-194.

5. Vogt I, Stumpfe D, Ahmed HEA, Bajorath J: Chem Biol Drug Des 2007, 70:195-205. 